\title{
DAYA HAMBAT AIR KELAPA (Cocos nucifera) TERHADAP PERTUMBUHAN BAKTERI Salmonella typhi dan Escherichia coli
}

\author{
Fera Sartika ${ }^{1}$ \\ 1Dosen Program Studi D-III Analis Kesehatan Universitas Muhammadiyah Palangkaraya \\ e-mail : Sartikafera3@gmail.com
}

\begin{abstract}
ABSTRAK
Produk dari kelapa diketahui memiliki aktivitas sebagai anti bakteri. Salah satu produk dari kelapa adalah Air kelapa. Air kelapa memiliki maanfat dalam pengolahan pangan terutama untuk kesehatan. Air kelapa mengandung tanin atau antidotum (anti racun) bersifat antibakteri yang akan menghambat pertumbuhan bakteri. Penelitian ini bertujuan untuk mengetahui efek antimikroba pada air kelapa dengan melakukan pengujian daya hambat terhadap bakteri Salmonella typhi dan Escherichia coli. Jenis penelitian ini menggunakan metode eksperimen atau percobaan (Experiment research). Sebelum dilakukan uji daya hambat terlebih dahulu dilakukan uji fitokimia dari air kelapa seperti senyawa flavonoid, Alkaloid, Tanin, Saponin dan steroid.

Simpulan: Hasil penelitian menunjukkan bahwa air kelapa tidak mengandung senyawa kimia flavonoid, Alkaloid, tanin, saponin, dan steroid. Pada hasil uji daya hambat menunjukkan bahwa air kelapa tidak dapat menghambat pertumbuhan bakteri Salmonella typhi dan Escherichia coli.
\end{abstract}

Kata kunci : Air Kelapa, Tanin, Salmonella typhi, Escherichia coli

\begin{abstract}
Coconut products are known to have anti-bacterial activity. One product of coconut is coconut water. Coconut water has benefits in food processing, especially for health. Coconut water contains tannin or antidotum (anti-poison) which is antibacterial which will inhibit bacterial growth. This study aims to determine the antimicrobial effects of coconut water by testing the inhibition of Salmonella typhi and Escherichia coli bacteria. This type of research uses experimental or experimental methods. Before the inhibitory test is carried out, phytochemical tests of coconut water are carried out such as flavonoids, alkaloids, tannins, saponins and steroids.

Conclusion: The results showed that coconut water does not contain the chemical compounds of flavonoids, alkaloids, tannins, saponins, and steroids. The results of the inhibitory test indicate that coconut water cannot inhibit the growth of Salmonella typhi and Escherichia coli bacteria.
\end{abstract}

Keywords: Coconut Water, Tanin, Salmonella typhi, Escherichia coli 


\section{PENDAHULUAN}

Indonesia kaya akan sumber daya alam khususnya sumber daya hayati yang meliputi berbagai jenis tumbuhan. Dari 40.000 jenis tumbuhan yang tumbuh di Indonesia, hampir 1.000 jenis diantaranya dapat digunakan sebagai bahan obat ${ }^{1}$. Salah satu tumbuhan di Indonesian adalah Pohon kelapa. Pohon kelapa dapat ditemukan hampir di seluruh provinsi di Indonesia dari daerah pantai yang datar sampai ke daerah pegunungan yang agak tinggi. Kelapa adalah tanaman serba guna karena setiap bagian tanaman bermanfaat bagi manusia, sehingga tanaman kelapa dijuluki "Tree of Life" Tidak hanya buahnya, tetapi seluruh bagian tanaman mulai dari akar, batang, sampai ke pucuk tanaman dapat dimanfaatkan².

Buah kelapa merupakan salah satu bahan baku dalam pengolahan pangan. Salah satu limbah dari buah kelapa adalah air kelapa. Air kelapa memiliki maanfat dalam pengolahan pangan terutama untuk kesehatan. Air kelapa mengandung tannin atau antidotum (anti racun). Tanin bersifat antibakteri yang akan menghambat pertumbuhan bakteri. Air kelapa diketahui dapat menghambat pertumbuhan bakteri patogen seperti Salmonella typhi dan Escherichia coli penyebab diare. Kandungan zat kimia yang terdapat pada air kelapa antara lain asam askorbat atau vitamin C, protein, lemak, hidrat arang, kalsium (potassium). Mineral yang terkandung pada air kelapa ialah zat besi dan fosfor, serta mengandung gula yang terdiri dari glukosa, fruktosa dan sukrosa ${ }^{3}$.

\section{METODE PENELITIAN}

Penelitian ini menggunakan metode eksperimen atau percobaan (Experiment research).

Penelitian dilaksanakan dii Laboratorium Mikrobiologi Fakultas IImu Kesehatan Universitas Muhammadiyah Palangka Raya. Pengujian daya hambat dilakukan dengan metode Kirby Bauer yang merupakan suatu metode rujukan dari WHO yang telah distandarisasi dan dievaluasi secara luas. Interpretasi ukuran zona hambat menggunakan penggaris yang dicocokan dengan tabel.

\section{Bahan Penelitian}

Bahan-bahan yang digunakan dalam penelitian ini meliputi: Air kelapa muda yang berusia sekitar 2,4 bulan, bakteri Escherichia coli ATCC 25922, bakteri Salmonella typhi media Barain Heart Infusion (BHI), media Eosin Methylene Blue (EMB), media Salmonella Shigella Agar (SSA), media Mueller Hinton Agar (MHA), medium Nutrien Agar (NA), Nacl 0,9\% steril, disc kosong, antibiotic Kloramfenikol 500 mg, dan standar Mc Farland 0,5 , kertas sarin

\section{Alat penelitian}

Alat yang digunakan dalam penelitian ini yaitu neraca digital, percolator, tali, corong, cawan porselin, becker glass, gelas ukur, Erlenmeyer, labu ukur, cawan petri, tabung reaksi, rak tabung reaksi, 
pipet ukur, ball pipet, jangka sorong, Laminar Air Flow (LAF), evaporator, waterbath, autoklaf, incubator, hot plate, Bunsen, korek api, pinset, oven, aluminium foil, dan plastic wrap

\section{HASIL DAN PEMBAHASAN}

1. Uji Fitokimia

Uji fitokimia dilakukan sebagai uji pendahuluan untuk melihat kandungan senyawa fitokimia yang terdapat pada air kelapa. Hasil uji fitokimia dapat dilihat pada tabel berikut:

Tabel 2. Hasil Uji Fitokimia Air Kelapa

\begin{tabular}{|l|c|}
\hline $\begin{array}{l}\text { Metabolit } \\
\text { Sekunder }\end{array}$ & Air Kelapa \\
\hline Flavonoid & - \\
\hline Alkaloid & - \\
\hline Saponin & - \\
\hline Tanin & - \\
\hline Steroid & - \\
\hline
\end{tabular}

+ : ada, - : Tidak ada

Hasil penelitian menunjukkan bahwa air kelapa secara kualitatif negatif atau tidak mengandung metabloit sekunder seperti Flavonoid, Tanin, Alkaloid, Saponin dan steroid. Dari hasil tersebut menunjukkan bahwa secara kualitatif air kelapa diduga tidak mempunyai kemampuan untuk mempercepat penyembuhan diare yang disebabkan oleh bakteri Salmonella typhi dan Escherichia coli.

Salmonella typhi dan Escherichia coli merupakan bakteri pathogen yang dapat menyebabkan diare pada manusia ${ }^{4}$.
Hasil penelitian uji daya hambat memperkuat analisis bahwa air kelapa tidak dapat digunakan untuk mengobati atau memeperkuat penyembuhan diare. Hasil yang didapat dari penelitian ini adalah sebagai berikut:

a. Uji daya hambat air kelapa terhadap bakteri Salmonella typhi dan Escherichiacoli

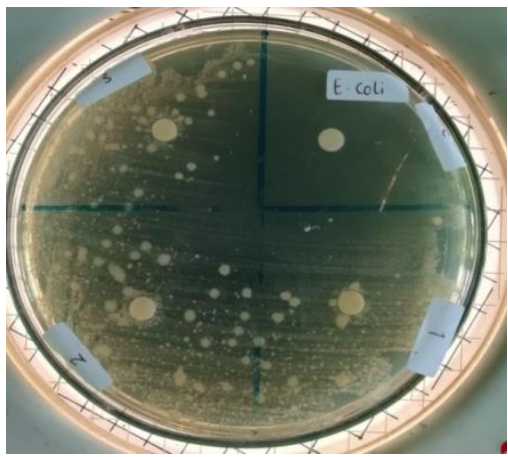

Gambar 3. Uji Daya Hambat Air Kelapa pada Bakteri Escherichia coli

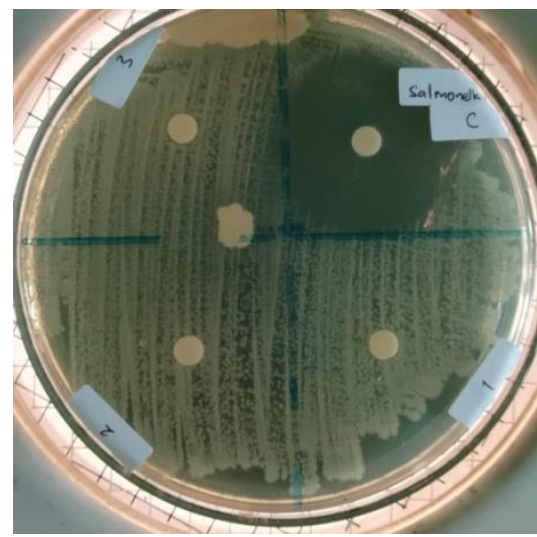

Gambar 4. Uji Daya Hambat Air Kelapa pada Bakteri Salmonella typhi

Produk dari kelapa diketahui memiliki aktivitas sebagai anti bakteri, oleh karena itu penelitian ini dilakukan untuk mengetahui bagaimana aktivitas anti 
bakteri dari air kelapa. Penelitian yang dilakukan oleh Khazanah (2018) menunjukkan bahwa air kelapa muda efektif dalam menghambat pertumbuhan bakteri E.coli, S. Typhi, dan Shigella sp. Namun dalam penelitian ini menunjukkan bahwa air kelapa tidak mampu menghambat pertumbuhan dari bakteri Salmonella typhi dan Escherichia coli. Tanda tidak adanya kemampuan daya hambat ditunjukkan dengan tidak adanya zona bening pada daerah sekitar kertas cakram (paper disc). Zona bening menunjukkan bahwa tidak ada pertumbuhan bakteri, artinya bakteri mengalami kematian, diduga karena zat yang terkandung dalam larutan uji. Penelitian ini sejalan dengan penelitian yang dilakukan oleh Kurniah (2012) dimana air kelapa muda (Cocos nucifera Linn var. Viridis) yang berusia 1-3 bulan tidak mampu menghambat pertumbuhan dari bakteri Salmonella typhi dan Escherichia coli. Tidak mampunya air kelapa muda dalam menghambat pertumbuhan bakteri, Salmonella typhi dan Escherichia coli diduga karena tidak adanya kandungan metabolit sekunder yang dapat menghambat pertumbuhan dari bakteri yaitu senyawa tanin yang memiliki kemampuan sebagai antibakteri. Selain itu perbedaan usia dan jenis kelapa memperkuat dugaan bahwa tidak semua kelapa memiliki kemampuan sebagai anti bakteri.

\section{KESIMPULAN}

Hasil penelitian menunjukkan bahwa air kelapa tidak dapat menghambat pertumbuhan bakteri Salmonella typhi dan Escherichia coli. Hasil penelitian uji daya hambat memperkuat analisis bahwa air kelapa tidak dapat digunakan untuk mengobati atau memeperkuat penyembuhan diare. Tidak mampunya air kelapa muda dalam menghambat pertumbuhan bakteri, Salmonella typhi dan Escherichia coli diduga karena tidak adanya kandungan metabolit sekunder yang dapat menghambat pertumbuhan dari bakteri yaitu senyawa tanin yang memiliki kemampuan sebagai antibakteri. Selain itu perbedaan usia dan jenis kelapa memperkuat dugaan bahwa tidak semua kelapa memiliki kemapuan sebagai anti bakteri.

\section{DAFTAR PUSTAKA}

1. Sarson, M.R.S., Wuisan, J., Awaloei, H. 2014. Uji Daya Hambat Ekstrak Daun Bawang Merah (Allium cepa. L) Terhadap Pertumbuhan Bakteri Escherichia coli. Manado : Skripsi Fakultas Kedokteran Sam Ratulangi.

2. Khasanah Tyas Ulfah. 2018. Uji Efektivitas Air Kelapa Muda Sebagai Antimikroba Terhadap Bakteri Escherichia coli, Salmonella typhi, dan Shigella sp. Penyebab diare .Skripsi. Universitas Muhammdiyah Purwokerto.

3. Lindawati, S.A., Haniyah, Y.S., Miwada, I.N.S., Suarta, I.GD. 2014. Antimicrobial Activity Of Yogurt-Based Coconut Water Inhibits Pathogen Bacterial In Vitro. ajalah IImiah Peternakan. 17 (2);51-551.

4. Amalia, R. 2016. Uji Daya Hambat Ekstrak Etanol Daun Sangkareho 
(Callicarpa longifolia Lam.) Terhadap Staphylococcus aureus. Palangka Raya. Karya Tulis IImiah. Universitas Muhammadiyah Palangkaraya.

5. Suwito widodo. 2010. Salmonella $s p$ and Escherichia coli Monitoring In The Animal Feed Ingredients. Buletin Peternakan. 34(3): 165-1

6. Cappucino, J. G. 2013. Manual Laboratorium Mikrobiologi Edisi 8. Terjemahan Nur Miftahurrahman dari Microbiology : a Laboratory Manual. Jakarta : Penerbit Buku Kedokteran EGC.

7. Fardiaz, S. 1989. Mikrobiologi Pangan. Bogor : IPB Press

8. Gabriel, J. F. 1988. Fisika Kedoktoran. Jakarta Penerbit Buku Kedokteran EGC

9. Gaman, P. M., dan Sherrington. 1992. Ilmu Pangan: Pengantar IImu Pangan, Nutrisi, dan Mikrobiologi Edisi Kedua. Yogyakarta : Universitas Gadjah Mada Press.

10. Kurniah. 2012. Uji Daya Hambat Air Kelapa Hijau ( cocos nucifera linn varietas. viridis) Terhadap Beberapa Bakteri Patogen: Skripsi. Fakultas IImu Kesehatan UIN Alauddin Makasar.

11. Noer Shafa, Pratiwi Rosa, D., Gresinta Efri. 2018. Penetapan Kadar Senyawa Fitokimia (Tanin, Saponin Dan Flavonoid Sebagai Kuersetin) Pada Ekstrak Daun Inggu (Ruta angustifolia L.). Jurnal IImu-IImu MIPA. 18(1): 1929

12. Pakekong, E.D., Homenta, H., Mintjelungan, C.N. 2016. Uji Daya Hambat Ekstrak Bawang Bombay (Allium cepa L) Terhadap Pertumbuhan Bakteri Staphylococcus aureus Secara In Vitro. Manado: Jurnal IImiah Farmasi Universitas Sam Ratulangi. 5(1);Hal.34-35. 